\title{
You Are Gods: Deification in the Naassene Writer and Clement of Alexandria
}

\author{
M. David Litwa \\ Virginia Tech
}

\section{Introduction}

Currently there is no widespread agreement on what constitutes gnosis or the gnostic identity in the ancient world. ${ }^{1}$ The best option, it seems, is to offer a polythetic classification wherein gnostic thinkers or groups possess a range of characteristics without any one group or thinker possessing all of them. ${ }^{2}$ Yet even if widespread agreement on a set of characteristics were attained, it still would not explain how gnostic groups emerged, developed, and crafted their own specific identities.

The situation is somewhat different for gnostic thinkers and groups that explicitly identified themselves as Christian. In this case, we possess abundant comparative material with other contemporary Christian groups variously called "catholic" and

${ }^{1}$ David Brakke argues that one can use the term "Gnostic" in a narrow sense to identify a particular Christian group in antiquity (The Gnostics: Myth, Ritual, and Diversity in Early Christianity [Cambridge, MA: Harvard University Press, 2010] 1-89). In contrast, Geoffrey S. Smith attempts to prove that "the Gnostic school" and the "Gnostics" are heresiological constructs "designed to consolidate a variety of unaffiliated Christian groups into one coherent and manageable category" (Guilt by Association: Heresy Catalogues in Early Christianity [Oxford: Oxford University Press, 2015] 152). European scholars continue to use "gnosis"/"gnostic" as global terms, with full recognition that these terms are heuristic and part of secondary (scholarly) discourse (e.g., Roelof van den Broek, Gnostic Religion in Antiquity [Cambridge, UK: Cambridge University Press, 2013]).

${ }^{2}$ For polythetic classification, see J. Z. Smith, Imagining Religion from Babylon to Jonestown (Chicago: University of Chicago Press, 1982) 4-5. The characteristics need not be solely doctrinal, but should involve ritual practice, disposition, and mythmaking. See the "idealized cognitive model" of April D. DeConick ("Crafting Gnosis: Gnostic Spirituality in the Ancient New Age," in Gnosticism, Platonism and the Late Ancient World: Essays in Honour of John D. Turner [ed. Kevin Corrigan and Tuomas Rasimus; NHMS 82; Leiden: Brill, 2013] 287-305, at 300-301).

HTR 110:1 (2017) 125-148 
"(proto-)orthodox." Using such comparative material gives us a better sense of how one set of gnostics (the Christian ones) emerged and understood the world, sacred texts, and divine reality in light of competing Christian discourses.

As a tool of comparison, the theme of deification is key. Deification appears in myths of salvation told by both gnostic and catholic Christians. In these myths, Christians transcend normally irrefragable human limitations (death, ignorance, subjection to the passions). Comparing Christian stories of deification is thus one way to tap into a larger network of similarities and differences between competing Christian movements in the second century CE.

In this essay, I focus on two roughly contemporary thinkers who cultivated a gnostic Christian identity: the Naassene writer and Clement of Alexandria. ${ }^{3}$ Their identity-forming praxis, as seen in similar mythmaking, allows us to meaningfully classify them as both Christian and gnostic. Why they generated a similar mythology is based largely on their absorption of a platonizing metanarrative assisted by a hermeneutic that comprehensively understood textual and historical phenomena in light of their Christ myth. The goal of my comparison is to indicate structural points of similarity in Christian gnostic myths and mythmaking in order to show the process of gnostic Christian identity formation in action. ${ }^{4}$

To focus my comparison, I concentrate on the Naassene and Clementine interpretations of Ps 82:6 (LXX 81:6: "I have said: you are gods, all of you children of the Most High"). ${ }^{5}$ Such a focus not only streamlines an ocean of data, but isolates a particular practice important for identity formation. As is well known, Christians formed their identities by inscribing themselves into the epic of Jewish scripture. ${ }^{6}$ By examining how two thinkers generated a myth of deification from the same Jewish text, we catch them in the act of constructing similar gnostic Christian identities.

\footnotetext{
${ }^{3}$ For Clement and gnosis, see Salvatore R.C. Lilla, Clement of Alexandria: A Study of Christian Platonism and Gnosticism (Oxford: Oxford University Press, 1971) 142-89; Peter (Panayiotis) Karavites, Evil, Freedom, and the Road to Perfection in Clement of Alexandria (VCSup 43; Leiden: Brill, 1999) 139-74; Arkadi Choufrine, Gnosis, Theophany, Theosis: Studies in Clement of Alexandria's Appropriation of His Background (Patristic Studies 5; New York: Peter Lang, 2002) 21-32; Andrew C. Itter, Esoteric Teaching in the Stromateis of Clement of Alexandria (VCSup 97; Leiden: Brill, 2009) 194-211; Holger Strutwolf, "Theologische Gnosis bei Clemens Alexandrinus und Origenes," in Zugänge zur Gnosis: Akten zur Tagung der Patristischen Arbeitsgemeinschaft vom 02.-05.01.2011 in Berlin-Spandau (ed. Christoph Markschies and Johannes van Oort; Leuven: Peeters, 2013) 91-112, at 93-100; Brakke, Gnostics, 32-34.

${ }^{4}$ The argument is thus not that Clement and the Naassene writer shared similar doctrines, but that they shared a similar soteriological myth that made sense of their doctrines. Cf. Brakke, Gnostics, 41-45.

${ }^{5}$ For a recent introduction to Ps 82 in its Hebrew Bible context, see Peter Machinist, "How Gods Die, Biblically and Otherwise: A Problem of Cosmic Restructuring," in Reconsidering the Concept of Revolutionary Monotheism (ed. Beate Pongratz-Leisten; Winona Lake, IN: Eisenbrauns, 2011) 189-240.

${ }^{6}$ Karen King identifies "the "correct' relationship to Jewish Scripture" as "the single most important factor in defining normative Christian identity" (The Gospel of Mary of Magdala: Jesus and the First Woman Apostle [Santa Rose: Polebridge, 2003] 155).
} 
Attention to Ps 82 also fills a gap in recent research. In 2005, Carl Mosser studied the second-century patristic interpretations of this psalm. ${ }^{7}$ He said nothing about the contemporary gnostic Christian use of it, even though he included other relevant comparanda from (significantly earlier) Second Temple Jewish texts and (significantly later) rabbinic writings. More disconcertingly, Mosser omitted a discussion of the four uses of Ps 82:6 in Clement's Stromateis, in which the Alexandrian applies the verse to gnostic Christians. In short, then, one can pick up where Mosser left off: studying these particular Clementine treatments in light of a contemporary gnostic Christian comparandum. ${ }^{8}$

\section{The Naassene Report}

The Naassene report opens book five of the Refutation of All Heresies, a polemical work completed about $225 \mathrm{CE}$ and attributed to Hippolytos of Rome. This attribution is by no means certain, and in this essay, I will call the writer simply "the author of Ref." 9

The Naassene report itself derives from a gnostic Christian document (or documents) dating from the mid to late second century CE. Richard Reitzenstein called the document a "sermon" (Predigt), and in her comprehensive study of the Naassenes, Maria Grazia Lancellotti continues to use this term. ${ }^{10}$ Regrettably, since the opening of the text is lost, its genre remains unclear.

\footnotetext{
${ }^{7}$ Carl Mosser, "The Earliest Patristic Interpretations of Psalm 82, Jewish Antecedents, and the Origin of Christian Deification," JTS 56 (2005) 30-74. See also Annewies van den Hoek, "'I Said, You are Gods ... ' The Significance of Psalm 82 for Some Early Christian Authors," in The Use of Sacred Books in the Ancient World (ed. L.V. Rutgers; Leuven: Peeters, 1998) 203-19; Norman Russell, The Doctrine of Deification in the Greek Patristic Tradition (Oxford: Oxford University Press, 2004) 121-40, esp. 128-31.

${ }^{8}$ In what follows, translations of the Naassene writer and Clement are my own. The page and line numbers in the most recent critical editions are given when particular words or phrases are cited.

${ }^{9}$ A version of the two-author theory for the Hippolytan corpus is now widely held. In Allen Brent's reconstruction, the author of Ref. is an anonymous early $3^{\text {rd }}$-cent. bishop who dies, leaving the community to a member of the same school - in fact the "real" Hippolytos who reconciles with the successors of Callistus (Hippolytus and the Roman Church in the Third Century [VCSup 32; Leiden: Brill 1995]). J. A. Cerrato accepts the theory of an eastern Hippolytos, probably from Asia Minor who composed the exegetical commentaries. For him, all links are severed between this genuine Hippolytos and the author of the Refutation (Hippolytus East and West: The Commentaries and the Provenance of the Corpus [Oxford: Oxford University Press, 2002]). See further M. David Litwa, Refutation of All Heresies Translated with an Introduction and Notes (Writings from the Greco-Roman World 40; Atlanta: SBL Press, 2016), xxvii-liii. The critical edition of Ref. used here is Miroslav Marcovich, Hippolytus: Refutatio omnium haeresium (PTS 25; Berlin, Walter de Gruyter, 1986).

${ }^{10}$ Reitzenstein, Poimandres: Studien zur griechisch-ägyptischen und frühchristlichen Literatur (Leipzig: Teubner, 1904) 82; Lancellotti, The Naassenes: A Gnostic Identity among Judaism, Christianity, Classical and Ancient Near Eastern Traditions (FARG 35; Münster: Ugarit-Verlag, 2000).
} 
Lancellotti and Tuomas Rasimus rightly reject Reitzenstein's idea that the Naassene report is a secondary christianization of an originally pagan document. They consider the document to be a genuinely Christian attempt to explain GrecoRoman myths from the standpoint of a consistent ideological perspective. ${ }^{11}$

The Naassenes explicitly identified themselves as Christians. In fact, they

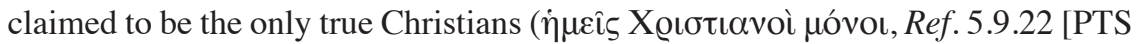
$25: 170.124])$. They identified the source of their tradition as Jesus, whose teaching was passed on through two successive tradents: James the brother of Jesus, and "Mariamme" (apparently Mary Magdalene) (Ref. 5.7.1).

The author of Ref. asserts that the Naassenes later identified themselves as "gnostics." He seems to have intuited this point from the Naassene writer's claim that his community "knows" ( $\gamma \iota v \omega ́ \sigma x \varepsilon เ v)$ the depths (Ref.5.6.4 [PTS 25:141.18]; cf. 5.23.3). ${ }^{12}$ It remains unclear whether the Naassenes used $\gamma v \omega \sigma \tau \iota x o$ oí as a technical group designation. ${ }^{13}$

According to the author of Ref.'s initial description, Naassene mythology includes both a Father and Son deity. The Father is the unknown, indeterminate Human. The Son of this Human is the determinate Logos later identified with Christ (Ref. 5.6.4; 5.7.33). In the author of Ref.'s later summary (Ref. 10.9.1 [PTS 25:384.3]), we learn that both the Human and Son of Human were called "Adamas"

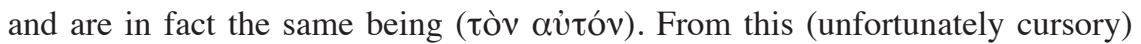
information, we might intuit that the Naassenes upheld a kind of consubstantiality between Father and Son similar to later Christian thought. To facilitate clarity, I will refer to the Father/Human as the Naassene "primal deity," and the Son of the Human as their "mediate deity." 14

The author of Ref. says that the Naassenes distinguished three forms in the mediate deity: intellectual, animate, and earthly (Ref. 5.6.6). ${ }^{15}$ The mediate deity contains, as it were, the Platonic Ideas for all three levels of being. ${ }^{16}$ All three

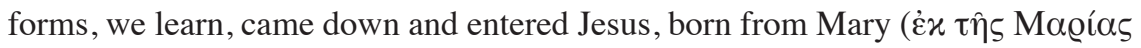

${ }^{11}$ Lancellotti, Naassenes, 10-29; Rasimus, Paradise Reconsidered in Gnostic Mythmaking: Rethinking Sethianism in Light of the Ophite Evidence (NHMS 68; Leiden: Brill, 2009) 187-88.

${ }^{12}$ Clement makes a similar use of "the depth of gnosis" (cf. Rom 11:33) in Strom . 5.8.54.3.

${ }^{13}$ See further Luise Abramowski, Drei christologische Untersuchungen (BZNW 45; Berlin: de Gruyter, 1981) 53-54; Brakke, Gnostics, 49. For the author of Ref.'s use of "gnostic," see M. J. Edwards, "Gnostics and Valentinians in the Church Fathers," JTS 40 (1989) 26-47, at 31-32.

${ }^{14}$ Hans-Martin Schenke argued that both the primal and mediate deity in Naassene thought are called Human, but only the mediate Human was enclosed in human bodies (Der Gott "Mensch" in der Gnosis [Göttingen: Vandenhoeck \& Ruprecht, 1962] 57-58). For Lancellotti, only the Naassene "second God" is the Human, but split into two aspects: one unformed, one trapped in matter (Naassenes, 75-77, 80, 82). Schenke provides the more plausible interpretation.

${ }^{15}$ From the epitome in Ref. 10.9.1, it is clear that the one divided into the three aspects is the mediate deity, or Son of the Human.

16 That there is a Platonic Idea of the body is indicated in Zostrianos (NHC VIII,1) 116.17-18: ousōma etemasteko ("[a bo]dy that remains uncorrupted"). 
$\gamma \varepsilon \gamma \varepsilon v v \eta \mu \varepsilon ́ v o v)$ (Ref. 5.6.7 [PTS 25:142.33-34]). ${ }^{17}$ Although the author of Ref. glides over this point, the fact that Jesus was born from Mary is significant. It gives us reason to surmise that for the Naassenes, Jesus had a physical birth, and that he was genuinely human. The mediate deity inhabited him at some unknown time.

By assuming the three forms of the mediate deity, Jesus could speak to three kinds of people: angelic, animate, and earthly (Ref. 5.6.7). We have little reason to think that these are rigid and impermeable classes, since each human being, it seems, is endowed with a portion of the mediate deity referred to as "the androgynous

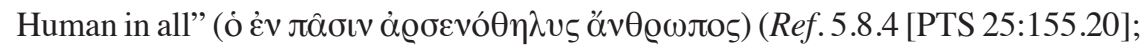
cf. 5.8.23). ${ }^{18}$ According to Lancellotti, the different groups indicate different levels of knowledge reached by individuals, without excluding the possibility of passing from one group to another. ${ }^{19}$

After his preliminary discussion, the Naassene writer turns to a bizarre and beautiful exegesis of a hymn to Attis (Ref. 5.7.10-9.6; the hymn is recorded in 5.9.8). Attis is allegorically taken to represent the Naassene mediate deity (Adamas) who meets the knower in many different mystery cults. The representatives of these cults did not realize the full import of their own myths (Ref. 5.9.7). Hence the Naassene author takes it upon himself to unveil their true meaning.

\section{Psalm 82:6}

The Naassene use of Ps 82:6 comes in an excursus in a section on Egyptian mysteries (Ref. 5.7.30-41). This excursus presents an allegorical exegesis of Hermes leading the suitors down to Hades in Homer's Odyssey (24.1-12). ${ }^{20}$ The exegesis repeatedly connects the Homeric and biblical text by means of hook words, a playful technique associated with rabbinic exegesis. ${ }^{21}$ I feign not to represent the thick intertextuality of this passage. My aim is to adequately describe the reading of Ps 82:6 with a view to the Naassene myth of deification.

${ }^{17}$ Cf. Irenaeus, Haer. 1.8.3. See further Antonio Orbe, Cristología Gnóstica: Introducción a la soteriología de los siglos II y III (2 vols.; Madrid: Biblioteca de Autores Cristianos, 1976) 1.416-17.

${ }^{18}$ Lancellotti, Naassenes, 130. For the Pauline image of the inner human, cf. 2 Cor 4:16; Rom 7:22; Eph 3:16. See further Theo K. Heckel, Der innere Mensch: Die paulinische Verarbeitung eines platonischen Motivs (WUNT 2/53; Tübingen: Mohr Siebeck, 1993).

${ }^{19}$ Lancellotti, Naassenes, 139-40.

${ }^{20}$ For the interpretation of this passage, see Lancellotti, Naassenes, 107-11; cf. 232-38.

${ }^{21}$ See further James L. Kugel, In Potiphar's House: The Interpretive Life of Biblical Texts (Cambridge, MA: Harvard University Press, 1994) 11-155; David Stern, Midrash and Theory: Ancient Jewish Exegesis and Contemporary Literary Studies (Evanston, IL: Northwestern University Press, 1996) 55-72. 
We first meet Hermes, taken to be a symbol of the Logos. ${ }^{22}$ The Logos is, in turn, another name for the Naassene mediate deity. In the allegory, the Logos is depicted as the psychopomp, or guide of souls. With the flick of his wand, he can awaken sleeping souls to their true, divine nature (Ref. 5.7.30, quoting Homer, Od. 24.3-5).

The suitors ( $\mu \nu \eta \sigma \tau \eta \dot{\varrho} \omega v)$ are allegorically those awakened from sleep who recall ( $\dot{\alpha} v \varepsilon \mu \nu \eta \sigma \mu \varepsilon \dot{\varepsilon} v \omega v)$ their divine origin. In the words of Empedokles, they remember "from what magnificent honor and what great beatitude [they have fallen]!" 23 The souls have fallen, the Naassene writer explains, from the blessed Human above, Adamas. They are brought down here into a bodily formation to serve Esaldaios, the Demiurge (Ref. 5.7.30).

Importantly, Hermes the Logos is also identified with Christ, who awakens souls as in Eph 5:14 ("Rise, you who sleep, and rouse yourself; then Christ will illuminate you!"). Christ, called "the son of the Human," is also identified with the mediate deity present in all people who are born (Ref. 5.7.33).

Using an image from Homer, the Naassene writer portrays Hermes-Christ as prodding souls that hang in a row like bats in a cave. The image derives from Odyssey 24.6-8, where Homer depicts the souls of the suitors as squeaky bats. The Naassene writer focuses on their rocky perch. He identifies it as $\alpha \delta \alpha ́ \alpha \alpha \varsigma$, which can be translated either as "adamant" or "Adamas." ${ }^{24}$ Souls, he says, originally hung from Adamas, the primal Human, but fell off in a flurry. It is the task of HermesChrist to root them back to their "rock" (Ref. 5.7.35).

Here we are not far from the allegorical imagination of Paul who wrote that Israel's rock spring in the Sinai desert "was Christ" (1 Cor 10:4). The Naassene writer does not appeal to this text but to a Jewish (Septuagintal) text which the Synoptic writers apply to Christ. The rock, he says, is "the cornerstone," "the one that has become head of the corner" (Ref. 5.7.35).$^{25}$ He then leaps to an Isaianic intertext:

I will install [that precious rock, the cornerstone] as the foundation stone of Zion. (Isa 28:16)

He understands the verse to mean that the rock, or Human, is the inner human "installed" in human beings. Thus, when the mediate deity Hermes-Christ meets human souls, he awakens something of himself within them. As psychopomp, Hermes-Christ leads the souls into eternal realms removed from all evil.

\footnotetext{
${ }^{22}$ The identification of Hermes and the Logos is common in Greco-Roman, Jewish, and Christian texts (e.g., Plato, Crat. 407e-408b; Herakleitos, All. 72; Philo, Legat. 94, 99; Plutarch, Is. Os. 54 [Mor. 373b]; Cornutus, Nat. d. 16.2, 11; Justin Martyr, 1 Apol. 22.2; Clement, Strom. 6.15.132.1; Ref. 4.48.2; 5.14.1; 5.17.8; Ps.-Clem., Rec. 10.41).

${ }^{23}$ Empedokles, DK 31 B119.165; also cited in Clement, Strom. 4.4.13.1.

${ }^{24} \mathrm{Cf}$. Irenaeus, Haer. 1.29.3.

${ }^{25}$ Ps 117.22 LXX, quoted in Matt 21:42; Mark 12:10; Luke 20:17; Acts 4:11; 1 Pet 2:7. Note

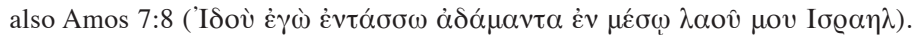


They go to a heavenly place, or in Homeric language, "past the streams of Ocean and Gleaming Rock" - the rock being another symbol of Adamas (Ref. 5.7.37) ${ }^{26}$ This whole process of the soul descending and returning above-the egressusregressus pattern - is symbolized by the ebb and flow of Ocean. The Naassene writer quotes two conflated Homeric lines:

Ocean, origin of gods and human beings. (Il. 14.201 and 246)

In its flow, Ocean - representing the cyclic stream of birth and rebirth - produces human beings. It brings down the souls from the primal Human and causes them to flow down into bodies. In its ebb, the same stream returns the souls back to their heavenly origin. This ebb, or epistrophe $\bar{e}$, is represented as the deification of souls.

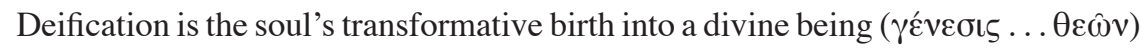
(Ref. 5.7.38 [PTS 25:153.215]).

Mention of deification immediately leads the Naassene writer to Ps 82:6:

I declared: "You are gods, and all of you children of the Most High!" (Ref. 5.7.39)

Rabbinic texts connect this verse with the giving of the Law at Sinai. The Israelites were deified (that is, immortalized) when they received the Torah. In other words, they returned to the primal state of Adam. But when they sinned by making the golden calf, they returned to mortality. ${ }^{27}$

\footnotetext{
${ }^{26}$ Homer, Od. 24.11-12.

${ }^{27}$ It is unwise to lean on very late rabbinic texts (e.g., Exodus Rabbah and Pirke de Rabbi Eliezer) to reconstruct an interpretive tradition of the $2^{\text {nd }}$ cent. CE. I cite here two earlier rabbinic passages that give a sense of the tradition. The Mekilta de-Rabbi Ishmael contains Tannaitic (late $1^{\text {st }}$ to $2^{\text {nd }}$ cent.) traditions, although probably redacted in the $3^{\text {rd }}$ cent. CE. Here we find a tradition attributed to Rabbi Jose: "It was upon this condition that the Israelites stood up before Mount Sinai, on the condition that the Angel of Death should have no power over them. For it is said: 'I said, You are gods,' etc. (Ps 82:6)" (Mekilta de-Rabbi Ishmael [ed. Jacob Z. Lauterbach; 3 vols.; Philadelphia: Jewish Publication Society, 1949] 2.271-72). Leviticus Rabbah is an Amoraic collection ( $3^{\text {rd }}$ to $4^{\text {th }}$ cent.) likely redacted in the $5^{\text {th }}$ cent. CE. In 11:3, a commentary on Prov 9:1-4, we read: "On the wing of the heights of the city (Prov 9:3) refers to the fact that the Holy One, blessed be He, enabled them [the Israelites] to fly, and attributed divinity to them (ויקרא אותן אלהות), as it is said You are gods (Ps 82:6). Now after all these favors . . . they forsook the will of the Holy One, blessed be He, and said of the calf, These are your gods, O Israel. For this reason, She said to him (Prov 9:4): Indeed you shall die like Adam [or: a mortal human being] (Ps 82:7)" (Midrash Vayyikra Rabbah: A Critical Edition Based on Manuscripts and Genizah Fragments with Variants and Notes [ed. M. Margulies; 5 vols.; Jerusalem: American Academy of Jewish Research, 1953-60], 1.222-23 [italics in original]). On these texts, see further Joel S. Kaminsky, "Paradise Regained: Rabbinic Reflections on Israel at Sinai," in Jews, Christians, and the Theology of the Hebrew Scriptures (ed. Alice Ogden Bellis and Joel Kaminsky; SBLSymS 8; Atlanta: SBL Press, 2000) 15-43, at 18-21, 33-39.
} 
The Naassene writer also connects the verse to the Israelites, but to an earlier part of their story: the Exodus. If souls flee from Egypt, he says, and cross the Red Sea, they will attain the heavenly Jerusalem. Egypt represents the world of mixture and generation. Crossing the Red Sea allegorically portrays their removal from earth to heaven. ${ }^{28}$

To support his interpretation, the Naassene writer employs John's gospel: "For all generation below, he says, is mortal, whereas the soul who is born above is immortal. For the spiritual human - not the fleshly - is born from water alone and spirit" (John 3:3, 5; cf. Ref 5.8.37). He then cites Jesus's statement in John 3:6: "What is born from flesh is flesh, and what is born from spirit is spirit." 29 These texts nicely sum up the Naassene writer's theory of deification: it is a form of spiritual rebirth promised by the Christian Savior (Ref. 5.7.40).

The Naassene writer uses a final water image. The flow of Ocean, he says, is like the Jordan River which rushes to prevent the children of Israel from leaving Egypt (here representing the body) (Ref. 5.7.39-41; cf. 5.8.2). It is Joshua — or rather Jesus

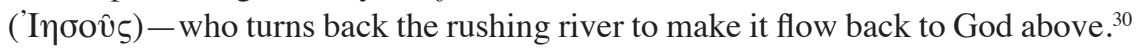

In short, the Naassene myth of deification involves the fall of preexistent souls from the Human God. The souls fall into the world of mixture and are incarnated. A Savior figure is necessary for the souls to be awakened and reborn (that is, deified). The Savior depicted is the Christian one. Jesus turns the waters of birth and death into the waters of rebirth, allowing escape from the cycle of generation.

In this myth, images from Homer and the Bible promiscuously blend. In the end, Christian images and language tend to predominate. Hermes morphs with Christ. The Naassene writer's allegory of Odyssey 24 is a Christian allegory (one of the first in a long history). His christological hermeneutic weaves Christian language and symbols so tightly into Homer's text that, if removed, the whole tapestry would unravel.

\section{Clement of Alexandria}

For most readers, Titus Flavius Clemens - or Clement of Alexandria-requires less of an introduction. Born around $150 \mathrm{CE}$ and instructed by a variety of Christian teachers in the circle of the Mediterranean, he taught in Alexandria around the turn of the third century. He died elsewhere, in Cappadocia or Palestine, around 215 (Eusebios, Eccl. hist. 6.6.1; 6.11.6). Clement comes to us unmediated in lengthy works, most significantly the Protreptikos, its sequel the Paedagogos, and (the

\footnotetext{
${ }^{28}$ The heavenly Jerusalem is an image found in Paul (Gal 4:26), Hebrews (12:22), and Revelation (3:12; 21:2, 10). Cf. also 2 Bar 4:2-7; 3:1; 2 En 55:2; Irenaeus, Haer. 5.35.2; Ref. 5.16.4-5; 6.34.3; Clement, Strom. 4.26.172.2-3.

${ }^{29} \mathrm{Cf}$. Clement, Strom. 3.12.84.3.

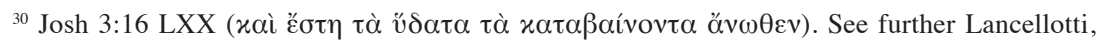
Naassenes, 160-62.
} 
apparently independent) Stromateis of Gnostic Explanations according to the True Philosophy. Mosser has already briefly treated the two uses of Ps 82:6 in the Protreptikos and Paedagogos. In what follows, I focus on the four uses in the Stromateis that Mosser omitted.

\section{Psalm 82:6}

The first interpretation comes in the context of radical asceticism and sacrifice. Clement praises the martyrs whom law-inspired reverence [here personified] trained to demonstrate their devotion to God through blood. This "reverence from the law," depicted as a pedagogue, leads to Christ (Strom 2.20.125.3 [GCS 15:181.3-5]; cf. Gal 3:24).

Clement then quotes Ps 82:1: "God stood in the congregation of gods; in the midst of gods he passes judgment." Although he does not say so explicitly, Clement hints that it is Christ who is the presiding deity, while Christian martyrs make up the deified congregation. ${ }^{31}$ Martyrs are models of those superior to passions and pleasures. Clement calls these Christians "gnostics" ( $\gamma v \omega \sigma \tau \iota x o u ́ \varsigma)$, who

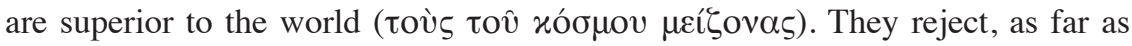

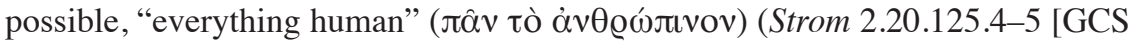
15:181.5-10]).

To reject "everything human" is a striking ethic, an ethic that Clement immediately supports with Pauline texts. Paul said that, at present, Christians are not "in flesh," but "in Spirit" (Rom 8:9), and that even in their current state, Christians do not war with fleshly weapons (2 Cor 10:3). In the end, "Flesh and blood will not inherit the kingdom of God" (1 Cor 15:50). "Flesh" ( $\sigma \alpha ́ \varrho \xi)$ here evidently indicates "all that is human." It cannot mean "body" per se (since Christians are presently in the body) but refers to the passions involved in bodily life. To enter God's kingdom requires that these passions be stripped away (Strom 2.20.125.6-126.1).

To some degree, this goal can be achieved while still in the body. The Christian gnostic who masters the passions while in the body is (in Clement's bold phrase) "a

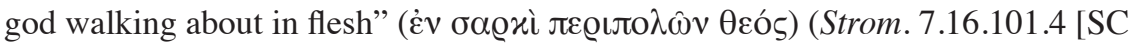
428:304.20-21]). As is well-known, the phrase is an allusion to Empedokles DK

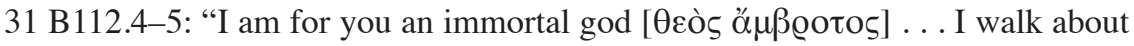
$[\pi \omega \lambda \varepsilon \hat{v} \mu \alpha \mathrm{l}]$ honored among all." 32 But Clement likely thought of Christ, whom

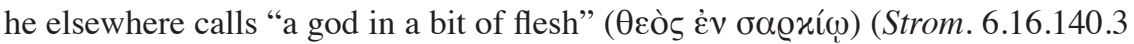
[SC 446:340.17]).

In Stromateis book 4, Ps 82:6 appears in a discussion of ascetic ethics. Clement supports what might be called a moderate asceticism. We ought not to reject the body and marriage, he says, but choose what is superior: disciplining the body and, as Paul recommends, not marrying (1 Cor 7:38, 35) (Strom. 4.23.149.1-2).

\footnotetext{
${ }^{31}$ Cf. Justin, Dial. 124.1.

${ }^{32}$ Cf. Epikouros, Ep. Men. 135.
} 
For Clement, creation is good. The God who loves good has made what is necessary obtainable. God has outfitted human beings by nature to become perfect by their own moral choices. Clement quotes Demokritos to the effect that "nature and teaching are nearly identical," inasmuch as both shape and fashion the human to the same end (DK 68 B33). God provides both a good creation, and a new creation through the (new) covenant (Strom. 4.23.149.3-5).

What human beings need to choose, according to Clement, is what is best of

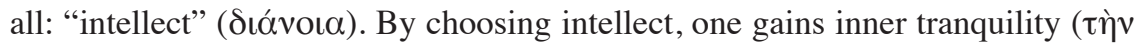

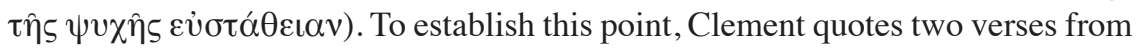
Proverbs that speak of rest gained from confidence. The latter, Prov 3:5, speaks

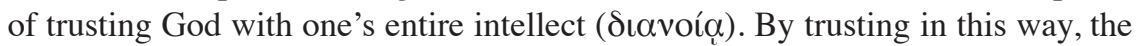

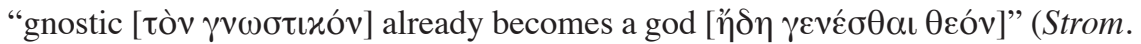
4.23.149.6-8 [SC 463:304-6.16-24]).

The mention of deification sparks a citation of Ps 82:6: "I have said you are

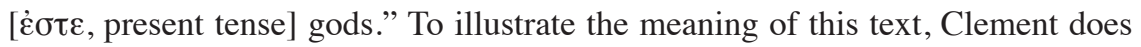
not appeal to the New Testament, but Empedokles, who says that the souls of diviners, singers, doctors, and leaders "bloom as gods best in honor" (Strom. 4.23.150.1 [SC 463:306.1-5]). ${ }^{33}$ Earlier in book 4, Clement uses the same verse from Empedokles that was quoted by the Naassene writer. The martyr, by living among human beings, shows "what magnificent honor and what great beatitude" he has abandoned (4.4.13.1). For Clement, as we saw, the martyr is the true gnostic (4.4.15.3-4; 4.7.52.2-3).

In book 6, Clement interprets the fifth commandment about honoring one's father and mother. Our spiritual father is God, he says, while our mother is Wisdom, whom Solomon calls "Mother of the righteous." ${ }^{34}$ God is our Father because Ps

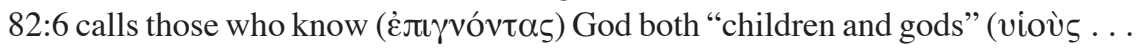
xà̀ $\theta \varepsilon o u ́ \varsigma)$. Although Clement does not explicitly mention the Christian gnostic

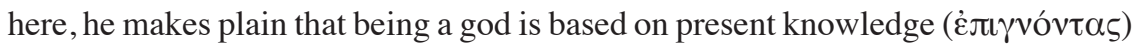
of God (Strom. 6.16.146.1-2 [SC 446:352.1-9]).

The final reference-or rather, allusion - to Ps 82 occurs in Stromateis book 7 , in a majestic passage about Christian gods. Those who are suspended from the Lord through faith, love, and gnosis rise with the Logos to God. In heaven, gnosis is handed over to those who are fit and selected for it by virtue of their preparation and training to advance beyond the righteousness according to law. ${ }^{35}$ This gnosis leads to an endless and perfect end, teaching the content of a future godlike life with the other gods. After being freed from punishments due to sin, divine honors are bestowed on the perfect, who are beyond all purification and service. They are

${ }^{33}$ DK 31 B146.

${ }^{34}$ This phrase has not been found in the LXX. Mgr. Patrick Descourtieux in Les Stromates: Stromate VI (SC 446; Paris: Cerf, 1999) 353, n. 3 can only point to the Latin version of Sir 3:1 (filii sapientiae). Yet Wisdom as Mother is a well-known Valentinian mytheme.

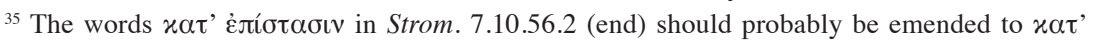

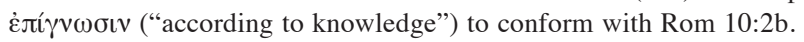


the pure in heart, restored to their heavenly station, eternally contemplating God while in close proximity to Christ. In this state, they are called gods - for that is what they are. Their station and rank confirm it: they are enthroned along with the other gods who are subordinate to the Savior alone (Strom . 7.10.56.1-6). ${ }^{36}$

One would think that Clement here speaks only about future deification. Yet he adds that gnosis is swift ( $\tau \alpha \chi \varepsilon i \hat{\alpha}$ ) to purify and fit for transforming human beings to what is superior (Strom. 7.10.56.7 [SC 428:184.21]). In the end, gnosis "easily transfers a person to the divine and holy [state] akin to the soul, and through a familial light transports him across the mystical stages of advancement, until it restores him to the uppermost place of rest. . . . For in this lies the perfection of the gnostic soul" (7.10.57.1-2).

What is evident from these passages is that Clement tends to cite Ps 82:6 in parenetic discourse. This makes his myth of deification more difficult to boil down. Suffice it to say that it involves human souls who, now in bodies, strive to achieve a passionless state. The struggle culminates in a separation from the body (for the martyr, a voluntary separation), a final purification, and a restoration of the gnostic to his or her heavenly and immortal state.

\section{Comparison}

When we compare the Naassene and Clementine myths of deification, we immediately expect difference. Partly this is due to our categories. One author is commonly classified as "gnostic" (which in some circles still has the resonance of "non-normative" or "heterodox"), and the other as "Patristic" and "(proto-) orthodox" (labels for a tradition on the basis of which theologians still construct their own Christian identities). But to historically reconstruct second-century Christian myth as constitutive of identity formation, one must disengage from the value judgments tacitly involved in these categories. After all, Clement himself later came under the cloud of "heresy," a suspicion that was used as an excuse to shelve and forget his works. ${ }^{37}$

We first note some of the more salient commonalities. Both Clement and the Naassene writer are highly educated Christian writers in the late second century working with mythologies heavily informed by Platonism. Both posit a central mediate deity and necessary Savior figure called "Christ" and the "Logos." Both point to passages in Empedokles and Jewish scripture to develop their theories of

\footnotetext{
${ }^{36}$ Bogdan Gabriel Bucur interprets deification in this passage as a form of angelification (Angelomorphic Pneumatology: Clement of Alexandria and Other Early Christian Witnesses [VCSup 95; Leiden: Brill, 2009] 45-49).

${ }^{37}$ Piotr Ashwin-Siejkowski, Clement of Alexandria on Trial: The Evidence of 'Heresy' from Photius' Bibliotheca (VCSup 101; Leiden: Brill, 2010).
} 
deification. Both associate Egypt with the body and its passions.$^{38}$ Both speak of salvation as rebirth and departure from material reality. ${ }^{39}$ Both call saved people "spirituals" ( $(\tau \varepsilon \varepsilon v \mu \alpha \tau \iota x o$ ) $){ }^{40}$ Both are avid readers of Greek poets (notably Homer) and openly display their knowledge of culturally elite poetry.

Nonetheless, there are serious theological differences between the two thinkers. Clement himself, in his attempt to prove the superiority of his version of Christian gnosis, was eager to stress (and essentialize) dissimilarities. To begin with, Clement does not view God as a primal Human. He does not believe that a portion of this Human has been bound within humanity. He believes that the primal deity - not lesser powers - created the human body and that this body is good (Strom. 3.4.34.1; Paed. 1.3.7.1). Clement resists the idea that Christians are or will become consubstantial with the mediate deity, strongly emphasizing free will and obedience to the creator.

Nevertheless, the polemical nature of Clement's discursive practice gives us reason to suspect that he highlights those portions of his mythology that are in fact variants of a more basic and widespread Christian myth. Below I highlight some of the structural elements of this mythology, focusing on elements relevant to Naassene and Clementine deification.

\section{The Savior}

We begin with the mythology of the mediate deity. For the Naassene writer, the Logos is the child of the Human, sharing the same divine Humanity as the primal God called "Mind" (Nóos) (Ref. 5.10.2 [PTS 25:171.6]). He contains the Ideas of all three levels of creation: intellectual, animate, and earthly (Ref. 5.6.6). For Clement, the Logos is the first creation of God (Exc. 19.3 [SC 23:94]), the supreme Son of God, equal to the Lord of the universe (Protr. 110.1 [VCSup 34:160.6]). He is the true Son of Mind (vovs) (Protr. 98.4 [VCSup 34:145.15-16]). Elsewhere

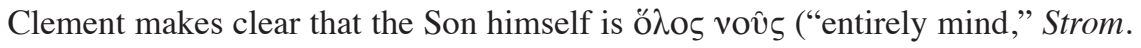
7.2.5.5 [SC 428:50.18], reminiscent of Xenophanes DK 21 B24), and is identified with the realm of Ideas ( $\chi \omega \dot{\varrho} \alpha$ idecov) (Strom. 4.25.155.2 [SC 463:316.11]). ${ }^{41}$

\footnotetext{
${ }^{38}$ Ref. 5.7.39-41; 5.8.2; cf. Clement, Strom. 1.5.30.4 (Egypt = secular world); 2.10.47.1 (Egypt $=$ the world and misguidedness, passions and vices).

${ }^{39}$ Ref. 5.7.40; Clement, Protr. 88.2; Ecl. 5.2.

${ }^{40}$ Ref. 5.9.4; Clement, Paed. 1.6.31.2; cf. Strom. 7.14.87.3.

${ }^{41}$ Alkinoos distinguished between the primal God as Mind at rest and the mediate God as Mind in activity (Epit. 10.2). See further John Dillon, The Middle Platonists 80 B.C. to A.D. 220 (2nd ed.; Ithaca: Cornell University Press, 1996) 282-84.
} 
The Naassene Logos, as awakener of souls, plays center stage in the drama of salvation. Clement uses the same image of the awakener-Logos and even quotes the same verse: "He [Christ] rouses from sleep . . 'Awake!' he says, 'O sleeper, and rise from the dead"' (Eph 5:14) (Protr. 84.2 [VCSup 34:126.5-6]). ${ }^{42}$ Both the Naassene writer and Clement represent the Logos as conductor ${ }^{43}$ and as a shepherd with a rod of iron. ${ }^{44}$

\section{Incarnation}

For the Naassene author, the mediate deity is Human and serves as the archetype

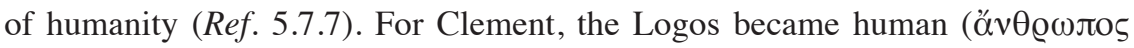

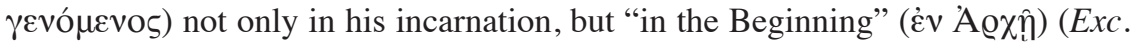
19.1 [SC 23:92]). Thus - although the primal God is not called Human - there is fundamental agreement on the mediate god's eternal humanity.

For Clement, the Logos becomes historically human in his incarnation (e.g., Paed. 1.5.23.1 [VCSup 61:16.1-2]). The incarnation is not an ontological, but a pedagogical necessity: "The Logos of God became human so that you also may learn from a human being how on earth a human may become a god" (Protr. 8.4 [VCSup 34:15.30-32]; cf. Paed.1.12.98.3). Clement is referring to Jesus as a model of asceticism and of the deified (i.e., passionless) life. The Logos, by assuming flesh, instructed it in the condition of passionlessness (Strom . 7.2.7.5; cf. 7.12.72.1). For the Naassene writer, the Logos also meets humanity in the fleshly Jesus, son of Mary. All three forms of the mediate deity inhabit Jesus, although the nature of this inhabitation is not entirely clear (Ref. 5.6.7).

\section{"Classes" of the Redeemed}

For the Naassene writer, Jesus speaks to three sorts of people: earthly, animate, and noetic (Ref. 5.5.6). Clement also presents a basic hierarchy of ordinary and gnostic Christians. He is fond of quoting Paul in 1 Cor 8:7: "gnosis is not the possession of

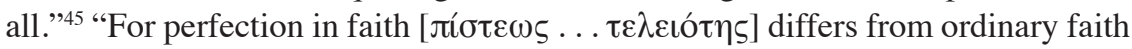

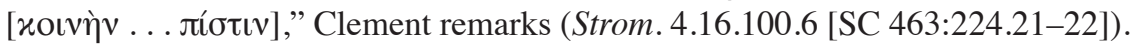

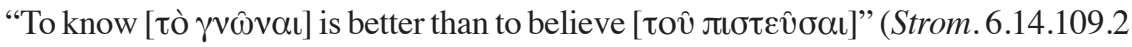
[SC 446:278.5]). Only the elect, those who have passed from faith to gnosis, can understand the holy mysteries of what is prophesied in parables (Strom . 6.15.126.2 [SC 446:312.6-9]; cf. 6.15.131.3).

${ }^{42}$ Cf. Clement, Paed. 1.8.66.3. See further Choufrine, Gnosis, 41-50.

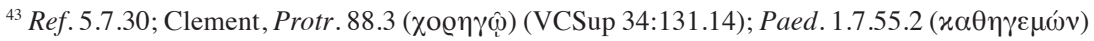
(VCSup 61:35.11-12).

${ }^{44}$ Ref. 5.7.32; Clement, Paed. 1.7.61.3 (VCSup 61:38.25-31).

${ }^{45}$ E.g., Clement, Strom. 6.15.132.3; 7.16.104.3. 
Elsewhere Clement offers a tripartite division of human beings: the gnostic, the believer, and the hard of heart. The Logos has three kinds of instruction for each of the three types. He teaches the first by the mysteries, the second by good hopes, and the third by corrective instruction (Strom . 7.2.6.1). ${ }^{46}$

Clement's idea that certain human beings will be attracted to the mediate deity as he speaks through Jesus is shared with the Naassene writer (Ref. 5.6.7). Clement calls the Logos "the truly heavenly and divine Eros" who approaches human beings, fanning into flame the true good ( forth (Protr. 117.2 [VCSup 169:5-7]).$^{47}$ The Logos amplifies the native intellectual power of human beings. He "clarifies the mind buried in darkness, and sharpens the light-bearing eyes of the soul" (Protr. 113.2 [VCSup 34:163.14-15]).

\section{The Divine Spark}

The Naassene writer presents a variety of (mostly biblical) metaphors for the divine spark in humanity: "the kingdom of heaven," "the mustard seed," (Ref. 5.9.6), and the pearl thrown into the bodily formation (Ref. 5.8.32). Nonetheless, his most frequent biblical image is the inner human (Ref. 5.7.36; 5.8.4; 5.8.23; cf. 2 Cor 4:16; Rom 7:22; Eph 3:16). The mediate deity, or Son of the Human, dwells

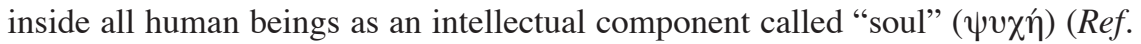
5.10.2; cf. 5.7.7-10).

Clement also uses diverse biblical metaphors for the divine spark, including "the elect seed," the "apple of the eye," "the mustard seed," "yeast," and, of course, "spark" itself (Exc. 1.3 [SC 23:54]). ${ }^{48}$ Elsewhere he speaks of an "inborn

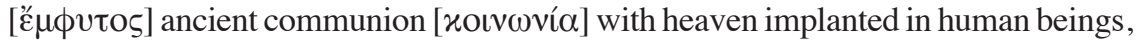
darkened by ignorance" (Protr. 25.3 [VCSup 34:36.9-11]). Human beings entirely

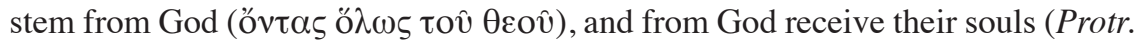
92.2 [VCSup 34:136.8-9]). God breathes into human beings something peculiar

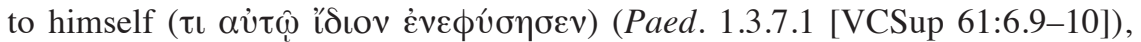

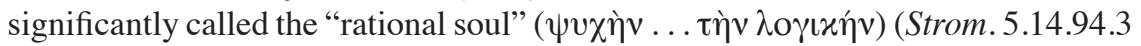
[SC 278:180.9-10]). ${ }^{49}$ Clement refers to a "divine emanation" (

${ }^{46}$ In Strom. 7.16.100.7, Clement presents another three-fold division, categorized by "three dispositions of the soul: ignorance, conceit and knowledge. Those in ignorance are the nations, those in knowledge are the true church, and those in conceit are the sectarians."

${ }^{47}$ Cf. Clement, Exc. 3.1.

${ }^{48}$ The importance of the divine spark in Clement was recognized long ago by G. W. Butterworth, "The Deification of Man in Clement of Alexandria," JTS 17 (1916) 157-69, at 158-59. See further Andrew C. Itter, Esoteric Teaching in the Stromateis of Clement of Alexandria (VCSup 97; Leiden: Brill, 2009) 124-27.

${ }^{49}$ Cf. é $\mu \phi u ́ \sigma \eta \mu \alpha$ in Paed. 1.3.7.3 (VCSup 61:6.13-14). For ǐ́ov in Paed. 1.3.7.1, Clement may depend on Wisd 2:23, or his version of it, wherein God makes humanity the "image of his own

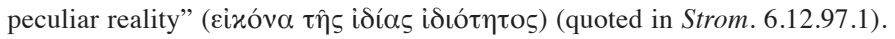




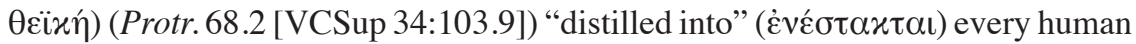
heart. This emanation is identified with "Mind" (vov̂s). Nov̂ $\varsigma$ is an "emanation"

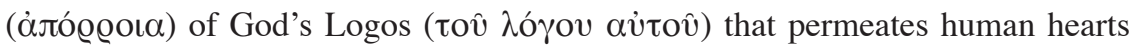

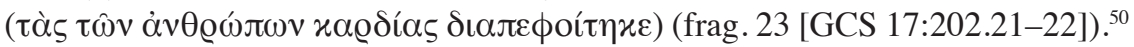

For Clement, the image of God dwells within and seems to be identified with the Logos, called our "co-inhabitant" (бúvoıxov) (Protr. 59.2 [VCSup 34.92.10]; cf. Paed. 3.1.1.5) ${ }^{51}$ The human nous is the image of the Logos (Strom 5.14.94.5 [SC 278:180.15-16]). Here, interestingly, Clement calls the Logos the "impassible

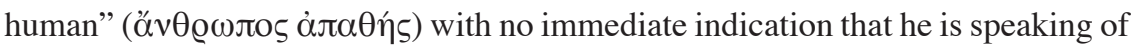
the Logos incarnate (cf. Exc. 19.1).

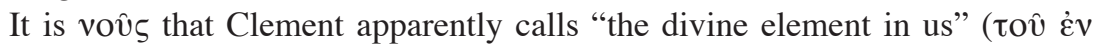

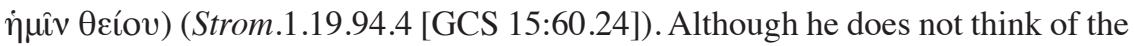
human vovs as a portion of the primal Human, Clement significantly identifies

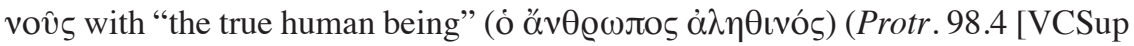

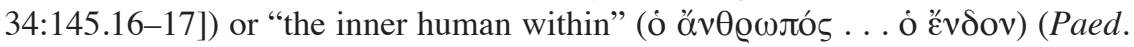
3.1.1.2 [VCSup 61:148.4]). ${ }^{52}$

\section{Consubstantiality}

The Naassene writer supports a soteriology in which the spiritual person who is reborn is consubstantial with the mediate deity (Ref. 5.8.10). ${ }^{53} \mathrm{He}$ bases this view on Jesus's statement in John 6:53 (conflated with Matt 5:20): “Unless you drink my blood and eat my flesh, you will certainly not enter the kingdom of heaven." The principle "you are what you eat" seems to be in view here: eat the substance ("flesh and blood") of Christ, become consubstantial with him. Yet the Naassene writer

\footnotetext{
${ }^{50}$ Christoph Markschies denied the authenticity of this fragment in part because he thought that the emanation of vov̌ was a gnostic idea ("'Die wunderliche Mär von zwei Logoi.' Clemens Alexandrinus, Frgm. 23-Zeugnis eines Arius ante Arium order des arianischen Streits selbst?" in Logos: Festschrift für Luise Abramowski [ed. Hanns Christof Brennecke, Ernst Ludwig Grasmück, and Christoph Markschies; BZNW 67; Berlin: de Gruyter, 1993] 193-219, at 210). This interpretation perpetuates Clement's own apologetic barrier between his gnostic theology and that of other gnostic

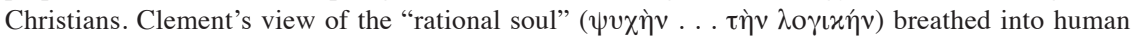
beings (Strom . 5.14.94.3 [SC 278:180.9-10]) is compatible with the Valentinian idea of the "rational

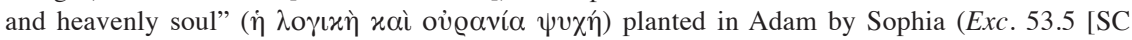
23:168]). In Quis div. 17.1, Clement writes: "For wherever the mind (o vov 5 ) of a human being is,

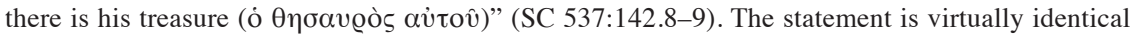
to what we find in Gos. Mary. (BG 8502,1) 10.15-16 (pma gar eterepnous ${ }^{e}$ mmau efmmau nči peho) (Nag Hammadi Codices V,2-5 and VI with Papyrus Berolinensis 8502, 1 and 4 [ed. Douglas M. Parrott; NHS 11; Leiden: Brill, 1979] 462).

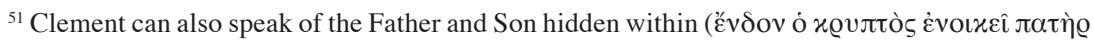

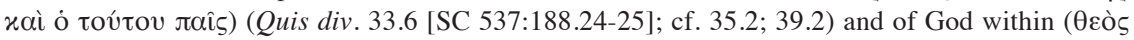

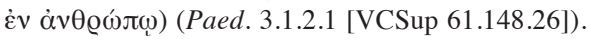

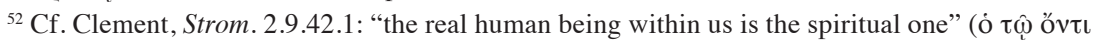

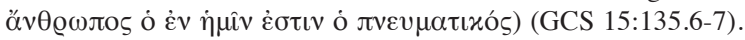

${ }^{53}$ See further Lancellotti, Naassenes, 108-9.
} 
adds an important point (through yet another gospel conflation): "But even if you drink the cup that I drink, you cannot enter the place where I go" (Ref. 5.8.11). ${ }^{54}$ In other words, those consubstantial with the Human are still not strictly speaking identical with him. The Naassene writer thus agrees with Clement that the mediate deity ultimately retains a higher rank.

Clement opposes the language of consubstantiality. It is audacious to say that we

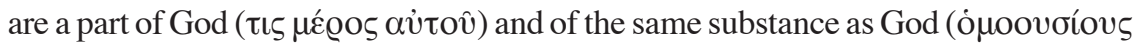

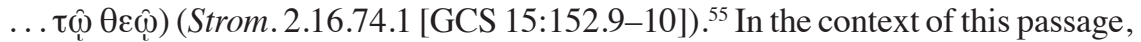
however, Clement is thinking of consubstantiality with the primal deity whom he

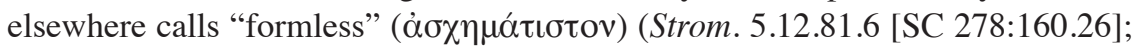
cf. Exc. 11.2). Even the Naassene writer would deny consubstantiality of this kind, inasmuch as the primal God is "formless" ( $\dot{\alpha} \chi \eta \mu \alpha ́ \tau \iota \sigma \tau o \varsigma)$ and unknowable (Ref. 5.7.18 [PTS 25:147.90]; 5.8.14) ${ }^{56}$ Both Clement and the Naassene writer, in other words, were agreed on the ultimate transcendence of the primal deity. ${ }^{57}$

The noetic nature of the mediate deity, however, allows for a kind of modified consubstantiality in Clement. He writes:

For the Logos of God is intelligible [voe@ós], according to which the image

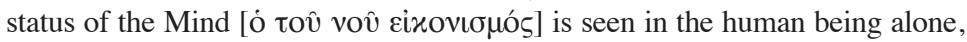

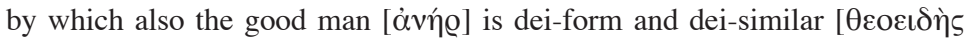
xoì $\theta \varepsilon o \varepsilon i ́ x \varepsilon \lambda o \varsigma]$ in his soul, and god, in turn, has the form of a human

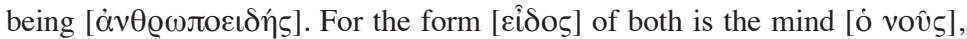

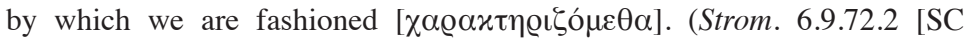
446:206.10-12] $)^{58}$

${ }^{54}$ Mark 10:38 (cf. Matt 20:22) combined with John 8:21 (cf. John 13:33; 7:34, 36).

${ }^{55}$ Clement rejects consubstantiality for reasons of theodicy. He believed (wrongly) that

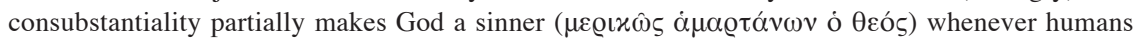
$\sin$ (Strom. 2.16.74.3 [GCS 15:152.13]).

${ }^{56}$ The adjective $\dot{\alpha} \sigma \chi \eta \mu \alpha \tau$ totó may go back to Plato's Parm. $137 \mathrm{~d} 8$, where the One is said to

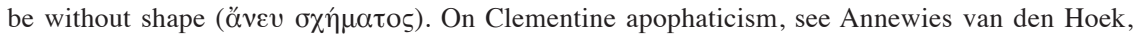
"God Beyond Knowing: Clement of Alexandria and Discourse on God," in God in Early Christian Thought: Essays in Memory of Lloyd G. Patterson (ed. Andrew B. McGowan, Brian E. Daley, and Timothy J. Gaden; Leiden: Brill, 2009) 37-60; Andrew Itter, "The Bosom of the Father: Notes on the Negative Theology of Clement of Alexandria," Eye of the Heart: A Journal of Traditional Wisdom 3 (2009) 29-36, at 32-35.

${ }^{57}$ Both writers agree with Alkinoos (Epit. 28.3) that humans assimilate only to the mediate deity; the primal deity is beyond reach. See further Dillon, Middle Platonists, 298-300. The God who has no "natural relation" ( not mediate deity (the Logos).

${ }^{58}$ The anthropomorphic "god" $(\theta \varepsilon \delta ́ \varsigma)$ is, in context, the Logos mentioned at the beginning of this passage. Cf. Strom. 4.25.162.5; 7.2.5.5. 
The "form" ( $\varepsilon \hat{\text { ¿ } \delta \circ \varsigma) ~ i n ~ t h i s ~ p a s s a g e ~ i s ~ p r o b a b l y ~ u s e d ~ i n ~ a n ~ A r i s t o t e l i a n ~ s e n s e . ~}{ }^{59}$ The Logos is the formal cause of humanity, and as a result, both have the same noetic form. At minimum, to share the same "form" of the Logos presumes some kind of ontological overlap. ${ }^{60}$

For Clement, the mediate God may not be Human, but he is the human form or archetype. Humans may not be consubstantial with the primal God, but their core self (or mind) is noetic. Human minds and the Logos are noetic on vastly different levels, perhaps, but they are ontologically alike. The mediate God and human beings are, as it were, part of the same class of noetic beings - even if the Logos occupies the very heights of that class and is son of the primal deity that transcends the class. This shared ontology is in fact what allows further ethical and ontological assimilation to the Logos. ${ }^{61}$

\section{Gnosis}

In both authors ethics of assimilation to the mediate god, gnosis plays a key role. In fact, this role is clearest in Clement, who in the Stromateis always applies Ps 82:6 to one who knows God and, in two uses of the verse, refers directly to the deified Christian "gnostic" ( $\gamma v \omega \sigma \tau \iota x o ́ s)$ (Strom 2.20.125.4 [GCS 15:181.7]; Strom. 4.23.149.8 [SC 463:306.24]).

Clement defines knowing God as enlightenment (Paed. 1.6.25.1 [VCSup 17:910]; cf. 1.6.29.3). "When gnosis dawns in enlightenment," he says, "it electrifies

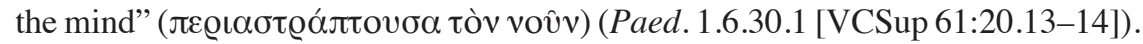

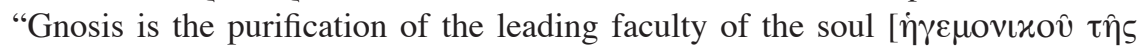

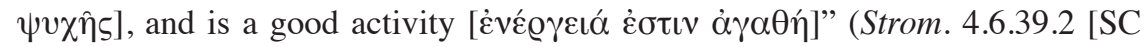
463:122.4-6]). In the same context, he remarks: "When, therefore, he who partakes gnostically of this holy quality, devotes himself to contemplation, communing in purity with the divine, he enters more nearly into the state of impassible identity, so as no longer to have knowledge and possess gnosis, but to be knowledge and gnosis" (Strom.4.6.40.1 [SC 463:124.2-5]). Such a transformation is an assimilation to the Logos, whom Clement calls “the gnosis of God” (Protr. 120.3 [VCSup 34.173.19]).

\footnotetext{
${ }^{59}$ In Strom. 8.9.28.2, Clement employs Aristotle's four causes and glosses the formal cause

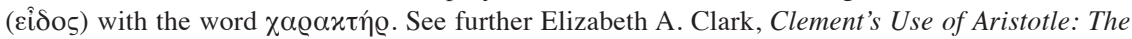
Aristotelian Contribution to Clement of Alexandrian's Refutation of Gnosticism (New York: Edwin Mellen, 1977) 84.

${ }^{60}$ Aristotle sometimes defines form in terms of substance, e.g., Met. 7.7, 1032b1-2: عî̉os $\delta \grave{\varepsilon}$

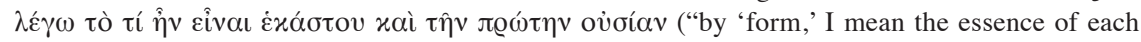

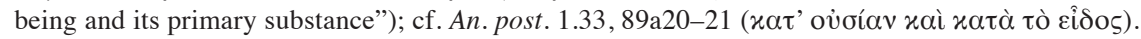
Clement denies Christians' equality with Christ, but his comments permit a kind of derived ( $\theta \varepsilon \dot{\sigma \varepsilon \varepsilon}$ ) ontological similitude (Strom. 2.17.77.3-5 [GCS 15:153.18]).

${ }^{61}$ Humans have the ability to become likenesses of the Logos through an intellectual process

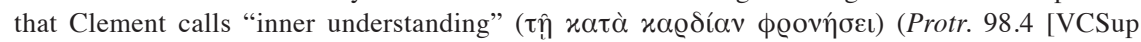
34:145.18-19]). Cf. Clement, Strom. 2.19.102.6; 3.5.42.6.
} 


\section{Ethics}

Gnosis is effective for salvation because gnosis assumes all the ascetic practices that make deification possible. ${ }^{62}$ Gnosis is the law of God inscribed on the heart since it includes ethical directives for which one needs neither an external source to learn nor an outside motivation to obey (Protr. 114.4). The law, Clement agrees with the

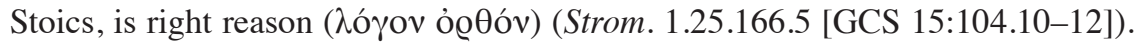
Deification is obedience to God, an obedience fully consonant with following one's own purified reason.

The connection of deification and obedience was popular in the late second century. ${ }^{63}$ The Naassene writer does not fail to note its importance. After quoting Matt 7:21 ("Not everyone who says to me, 'Lord, Lord!' will enter the kingdom of heaven, but the one who does the will of my Father in heaven"), he comments: "This remark shows that it is those who act-not just hear-who enter the kingdom of heaven" (Ref. 5.8.27-28; cf. Jas 1:22). Indeed, there would seem to be no aversion to law in the Naassene system given that the primal God himself is called Nó $\mu 5$ (Ref. 5.10.2 [PTS 25:171.6]; cf. Clement Protr. 98.4).

Twisting the rhetorical knife, Clement accuses his opponents of "obstinate

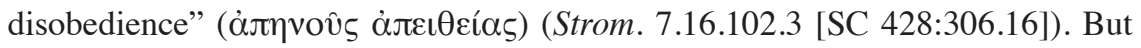
such a sharp contrast again occludes important commonalities. Gnostic Christian theologians (the Naassene writer among them) did not view the creator as the true God, but as a demonic usurper. Nor did they emphasize the need for a concerted rebellion against the creator. (The Naassene writer, from what we can tell, barely mentions the demiurge Esaldaios.) Both Clement and the Naassene writer fought a demonic infrastructure (variously imagined). Yet both were more focused on pleasing the one they viewed as the primal deity and his true mediator (the Logos).

\section{Marriage and Procreation}

The author of Ref. leads us to think that the Naassene author rejected sex, and by extension marriage and childbearing (Ref. 5.7.14; 5.9.11). Clement openly opposes such rigorous asceticism (Strom. 3.6.45-48). As we saw, however, he also advocated the single life for the gnostic Christian and thus upheld sexual abstinence as the ideal state (Strom. 4.23.149.1-2). ${ }^{64}$

\footnotetext{
${ }^{62}$ See further John Behr, Asceticism and Anthropology in Irenaeus and Clement (Oxford: Oxford University Press, 2000) 185-89, 195-201.

${ }^{63}$ Theophilos of Antioch, for instance, wrote that humanity was created neither mortal nor immortal, but in an intermediate state (Autol. 2.24). If Adam turned "to the life of immortality by keeping the commands of God, he would win immortality as a reward from God and would become

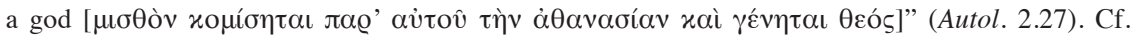
Irenaeus, Haer. 4.38.3; Clement, Paed. 1.12.98.

${ }^{64}$ Sexual abstinence is deeply rooted in Christian eschatology. See B. Lang, "No Sex in Heaven: The Logic of Procreation, Death, and Eternal Life in the Judaeo-Christian Tradition," in Mélanges bibliques et orientaux en l'honneur de M. Mathias Delcor (ed. A. Caquot, S. Légasse and M. Tardieu; Neukirchen-Vluyn: Neukirchener, 1985) 237-53.
} 
The Naassene and Clementine restrictive attitude toward sex and marriage can be traced to a common ethical goal: the subordination of bodily passions. Both theologians believe in the full cutting off of the passions ( $\dot{\alpha} \alpha \dot{\alpha} \theta \varepsilon \iota \alpha)$. The Naassene writer represents this cutting with the image of Attis's castration (Ref. 5.7.13, 15) ${ }^{65}$

For the Naassene writer, castration has the additional implication of removal from generation itself. The "male power of the soul" (the true self or divine spark) is meant to depart completely from the body and rise to God (Ref. 5.7.13). In his ethics, Clement showed astounding care for the body: how it was to be cleansed, dressed, fed, and so forth (Paed. 2-3). In the end, however, he too envisioned a final separation of soul and body (Strom. 4.3.12.5; cf. 6.12.100.3), inasmuch as the gnostic is already, in himself "without flesh" (ö $\sigma \alpha \varrho \varkappa o \varsigma)$ (Strom . 7.12.79.3 [SC 428:242.14]) and has rejected everything human (2.20.125.5). He approvingly quotes Plato's Phaedo (114c): “Those who by philosophy have been sufficiently

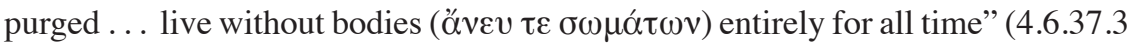
[SC 463:118.8-10]).

\section{The Quality of Divine Life}

For the Naassene writer, deification is not just the immortal continuation of this form of life. It means attaining ingeneracy, or breaking out of the wheel of birth and

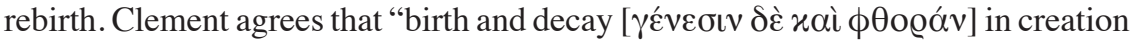
must providentially take place until the time of total separation and the restoration

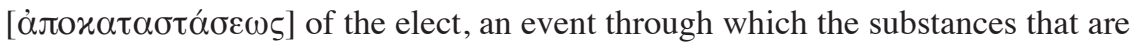

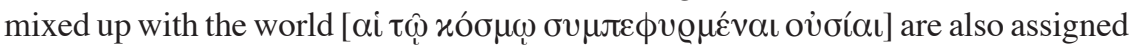

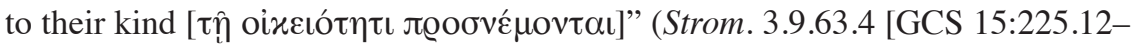
15]). ${ }^{66}$ The soul is one day destined to rise above the seven heavens and escape

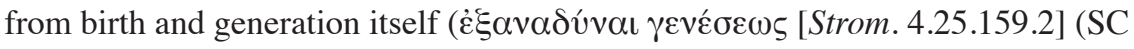
463:322.10)]; cf. $\gamma \varepsilon v \varepsilon ́ \sigma \varepsilon \omega \varsigma$ ن் $\varepsilon \xi \alpha v \alpha \beta \hat{\alpha} \sigma \alpha$ [Strom.4.25.155.4 (SC 463:316.17)]).

\section{Hermeneutics}

Finally, the Naassene and Clementine use of allegorical exegesis shows commonality in both form and content. Striking is their allegory of rebirth. For the Naassene writer, the Jordan River prevents the spirituals from leaving Egypt

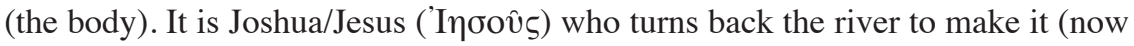
the vehicle of reborn souls) flow back to God above. Scriptural support comes from John 3:5, where rebirth occurs through water and Spirit (Ref. 5.7.40-41). Similarly, for Clement, the river Jordan, signifying matter (

\footnotetext{
${ }^{65}$ For the castrated Attis, cf. Clement, Protr. 19.4; Philippe Borgeaud, Mother of the Gods: From Cybele to the Virgin Mary (trans. Lysa Hochroth; Baltimore: Johns Hopkins, 2005) 105.

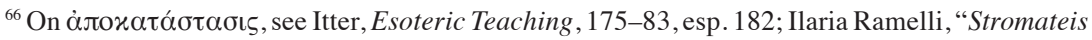
VII and Clement's Hints at the Theory of Apokatastasis," in The Seventh Book of the Stromateis: Proceedings of the Colloquium on Clement of Alexandria (Olomouc, October 21-23, 2010) (ed. Matyáš Havrda, Vít Hušek, and Jana Plátová; VCSup 117; Leiden: Brill, 2012) 239-60.
} 
ช้ $\lambda\rceil \varsigma)$, must be cut off and come to an end. The righteous person must come out

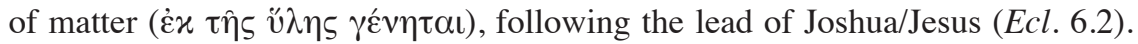
To support his interpretation, Clement also quotes John 3:5, affirming that rebirth occurs "through water and spirit" ( (Ecl.7.1 [GCS 17:138.20-26]).

Since they both interpret cultural phenomena in terms of their respective Christ myth, the Naassene writer and Clement show an unusual openness to symbols from other Mediterranean religions. Clement interprets the sphinxes outside of Egyptian temples to signify the enigmatic nature of God (Strom. 5.5.31 .5) ${ }^{67}$ The Naassene writer understands the phallic symbols outside the same temples to be symbols of the Good (Ref. 5.7.27-28). The latter uses lines from Homer to speak of the activity of the Logos and the prehistory of souls. Clement quotes a Homeric cento that mysteriously speaks of Father and Son (Strom . 5.14.116.1) and makes the same poet a witness to his own apophatic theology (Strom. 5.14.117.1-2) ${ }^{68}$

In his openness to voices from different religions, however, the Naassene writer outstrips Clement. Clement hears the song of the Logos in Homer, but also the siren song of adultery and idolatry. Some truth, he asserts, is symbolically expressed in the Greek mysteries (Strom . 5.11.70.7), but in the Protreptikos (an open attack on Greek religions), he parades his moral disgust (Protr. 11-23). Such a rhetorical pose may be due to his audience (the unconverted "Greek"). The Naassene writer (in the report we possess) does not speak to religious outsiders, but to his own fellow Christians. His approach better resembles Romantic historiography in which all mythologies are symbols of universal religious truth. ${ }^{69}$

Importantly, however, the "universal" Naassene truth was also Christian truth and the application of a christological hermeneutic. The divine Human can be found in all the mysteries - and this Human is Christ. Clement creatively - even prodigally - applied his christological hermeneutic to the Septuagint and (to a lesser extent) Greek poets. The Naassene writer applied a similar comprehensive hermeneutic to understand the myths of other Mediterranean religions.

\footnotetext{
${ }^{67}$ See further John Herrmann and Annewies van den Hoek, "The Sphinx: Sculpture as a Theological Symbol in Plutarch and Clement of Alexandria," in The Wisdom of Egypt: Jewish, Early Christian and Gnostic Essays in Honour of Gerard P. Luttikhuizen (ed. Anthony Hilhorst and George H. van Kooten; Leiden: Brill, 2005) 285-310.

${ }^{68}$ See further Michel Fédou, "La référence à Homère chez Clément d'Alexandrie et Origène," in Origeniana Octava: Origen and the Alexandrian Tradition (ed. L. Perrone; Leuven: Leuven University Press, 2003) 377-84, at 378.

${ }^{69}$ I hesitate to call the Naassene writer's attitude a "Seekership Outlook and Quest Orientation" (DeConick, "Crafting Gnosis," 300-301, following Wade Clark Roof, Spiritual Marketplace: Baby Boomers and the Remaking of American Religion [Princeton: Princeton University Press, 1999] 46-76). The Naassene Christians are entirely certain that they have found the truth. It is in fact this very certainty that enables them to be so open about seeing truth in places that contemporary catholics believed were haunted by demons.
} 


\section{Conclusion}

Clement asserts that the Christian "heretics" differ with him in regard to "first

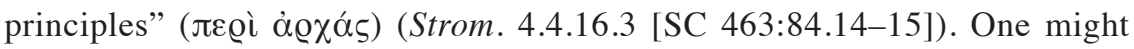
redescribe "first principles" as his basic mythological starting points. Significantly, it is precisely in the fundamental structure of Naassene and Clementine mythology that we regularly see similarity in difference.

Both Clement and the Naassene writer construct an apophatic primal deity. At the same time, they highlight an active mediate deity called Christ or the Logos. This mediate deity has a special relation to human beings. The relation is conceived of in ontological terms: the core of the human being is noetic, the same reality as the Logos himself. Salvation involves identifying with this core, the true human within, through disciplining the body and subduing the passions. Salvation, understood as deification, will be fully achieved when the flesh is transcended and the true human soars to its heavenly home. This is the platonizing "micromyth" underlying the thought of both Clement and the Naassene writer. ${ }^{70}$

Both authors go beyond Platonism by positing the active intervention of a mediate deity who becomes the Savior. In order to operate below, the Savior assumes or somehow involves himself with the lower elements - though he is never dominated by them. The Savior can only redeem a group of humans: the elect who-by a mix of disposition and choice-come to know both him and themselves. This shared mythology of the Savior - still informed by broadly Platonic thinking - becomes a key site of (elite) Christian identity formation. In brief, such mythmaking made late second-century intellectual Christians Christian.

Clement and the Naassene writer further develop their shared micromyth in a way that produces inevitable mythic variants. The Naassene writer, for instance, advocates consubstantiality with the Savior, while Clement insists on their similar noetic form. Such mythological variants generate subtle and important differences in attitude, ethics, and aesthetics - but none of them annul basic similarities in mythmaking practice. Both writers are trying to persuade their readers that the highest human goal (deification) occurs through some kind of ontological conformation to their particular mediate deity. They both teach that a human noetic or spiritual core makes such conformation possible. Their mythic discourse attempts to generate an elite (inevitably small) community that engages in reading and reflective practices that further develop the noetic core. The shared mythmaking praxis, in short, helps generate elite communities of Christian gnostics ("knowers").

\footnotetext{
${ }^{70}$ I borrow the term "micromyth" from Wendy Doniger (The Implied Spider: Politics and Theology in Myth [New York: Columbia University Press, 2011] 88-89). It refers to a non-occurring myth that contains the basic elements from which all possible variants are generated.
} 
Thus on the level of mythmaking practice (and probably social standing), Clement and the Naassene writer are not worlds apart. They are not representatives of two completely different movements (one orthodox and godly, the other "heretical" and satanic). Instead, they are contemporary theological siblings and rival Christian mystagogues striving to make their versions of esoteric Christianity appealing to fellow Christians with similar (intellectualist) dispositions.

There is a further dimension of practice shared by the Naassene writer and Clement. Both operate with a hermeneutic based on the metaphysics of Christ as the creative and all-encompassing Logos. This hermeneutic allows them to interpret Jewish texts as propounding deification. To the modern reader, texts like Ps 82 do not necessarily refer to deification at all. Nothing requires the gods addressed in verse 6 to be Christians (as opposed to angels, human judges, demoted deities, and so on). Yet when one combines the shared Platonic intellectual culture with the christological hermeneutic, a "deific" reading is activated. If Christ, God's Logos, is the speaker of the Psalms, he is the one who proclaims that Christians are his siblings and fellow gods in the divine congregation (cf. Heb 2:11-12). In this reading, Ps 82:6 poignantly described the strange situation in which gnostic Christians found themselves in late antiquity: by virtue of their noetic core and moral excellence, they were divine-yet they died like mortals.

In his study of Ps 82, Mosser claimed, "Without exception, in the earliest extant post-biblical Christian interpretations of Ps 82.6 the most significant phrase is the declaration to divine sonship, not the declaration of godhood." ${ }^{71}$ The evidence from both Clement and the Naassene writer undermines this thesis. To be sure, Clement holds that Christians are children of God, a common metaphor of Christians' close (kin-like) relationship to God (e.g., Strom. 6.14.114.5; 2.22.134.2). He highlights sonship in his interpretation of the fifth commandment where he cites Ps 82:6 (Strom. 6.16.146.2). On the whole, however, Clement's other uses of the verse in the Stromateis do not focus on the psalm's phrase "children of the Most High," and it is in these uses that we see Clement's "independent development." ${ }^{\prime 2}$ Christian gnostics are on a journey to become mediate gods. To become God's child meanswithout apology - to become a god.

Mosser's larger aim was to offer the death blow to Harnack's theory of Christian deification as "acute Hellenization." Deific readings of Ps 82:6, Mosser argued, appear in Jewish texts and follow from Pauline and Johannine theology. Mosser wrongly concluded, however, that hellenistic influence on the interpretation of

\footnotetext{
${ }^{71}$ Mosser, "Earliest Patristic Interpretation," 73.

${ }^{72}$ Ibid., 55. Mosser's judgment that in Paed.1.26.1-2 "children of the Most High" is most important while "you are gods ... takes on a secondary importance" is arbitrary (ibid., 57). Immortalization

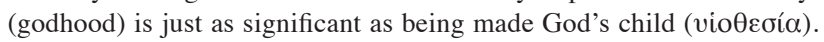


Ps 82 was "primarily linguistic and secondary." 73 He greatly underplayed the hellenization of Jews in the late Second Temple period (in this respect ironically following Harnack). ${ }^{74}$

Somewhat strangely, Mosser also omitted mentioning that acute hellenization was Harnack's primary metaphor for gnostic Christianity. ${ }^{75}$ In effect, Mosser argued that the patristic interpretation of Ps 82:6 was not gnostic (i.e., unorthodox) - a conclusion that replicates heresiological discourse. ${ }^{76}$

The results of this study throw Mosser's reading into question, given the fact that 1) it was gnostic Christians (the Naassenes) who supported a deific reading of Ps 82:6, and 2) Clement's own deific reading of Ps 82:6 directly applies it to the Christian gnostic. In the end, gnosis, or deep knowledge of the Christian mysteries, is profoundly related to deification and helps makes it possible.

To be sure, the deific reading of Ps 82:6 was not due to the "acute hellenization" = "gnosticizing" of Christianity (as if gnosis were a secondary contamination or disease). Elite knowledge had long played a role in Christian salvation - at least since the days of Paul (1 Cor 2:6-7; 8:1,7).$^{77}$ Before Christianity, elite knowledge played a soteriological role in esoteric forms of Judaism. What is important for this study is that Christian gnostics (like the Naassenes) were acting very much like contemporary catholics (e.g., Clement) when they interpreted Jewish texts (e.g., Ps 82:6) in light of a platonizing Christian myth. Out of this exegetical practicewhich hybridized Jewish and Platonic mythology - a Christian story of salvation as deification was formed. This story shaped the identities not just of those who belonged to the "Gnostic school" (as recently defined by David Brakke ${ }^{78}$ ), but the identities of a variety of gnostic Christian groups and thinkers including Clement and the Naassene writer.

${ }^{73}$ Ibid., 73.

${ }^{74}$ Mosser mentions hellenization only briefly in his final footnote (ibid., n. 75). On hellenization, see Litwa, Iesus Deus: The Early Christian Depiction of Jesus as a Mediterranean God (Minneapolis: Fortress Academic, 2014) 6-16.

${ }^{75}$ Adolph Harnack, History of Dogma (trans. Neil Buchanan; 7 vols.; Edinburgh: Williams \& Norgate, 1894) 1.226-27. See further Karen King, What is Gnosticism? (Cambridge, MA: Belknap Press, 2003) 55-70.

${ }^{76}$ Russell too attempts to elide any connection of Clementine deification to Gnosticism (Doctrine of Deification, 139). The distinction between a "true" and a "false" gnosis also reinstantiates heresiological discourse (André Méhat, "'Vraie' et 'fausse' gnose d'après Clément d'Alexandrie," in The Rediscovery of Gnosticism: Proceedings of the International Conference on Gnosticism at Yale (ed. Bentley Layton; 2 vols.; Leiden: Brill, 1980) 1.426-33. For a study of how scholarship has reinscribed and elaborated heresiological discourse, see King, What is Gnosticism, 5-148.

${ }^{77}$ See further Walter Schmithals, "The Corpus Paulinum and Gnosis," in The New Testament and Gnosis: Essays in Honour of Robert McL. Wilson (ed. A.H.B. Logan and A.J.M. Wedderburn; London: T\&T Clark, 1983) 107-24; Birger A. Pearson, "Mystery and Secrecy in Paul," in Mystery and Secrecy in the Nag Hammadi Collection and Other Ancient Literature: Ideas and Practices. Studies for Einar Thomassen at Sixty (ed. Christian H. Bull et al.; NHMS 76; Leiden: Brill, 2012) 289-302.

${ }^{78}$ Brakke, Gnostics, 29-89. 
To close: just as there is widespread recognition in the study of Jesus and Paul that the "Judaism vs. Hellenism" divide has collapsed, so there is increasing recognition in Gnostic and Early Christian studies that the wall separating "Gnosis/ Gnosticism" and "Christianity" is without foundation. To be sure, there were nonChristian gnostic sects (whose origins are still vigorously debated). Nevertheless, there were also gnostic groups so thoroughly Christian that contemporary catholic apologists spared no effort in their rhetorical attempt to make them seem "other" and alienated from the "true" Christian myth. It was the threat of similarity that built the wall of (supposedly insurmountable) difference. ${ }^{79}$ This study is offered as yet another pick to undermine that wall.

${ }^{79}$ J. Z. Smith, Relating Religion: Essays in the Study of Religion (Chicago: University of Chicago Press, 2004) 245. Cf. Gerd Theissen, A Theory of Primitive Christian Religion (London: SCM Press, 1999) 44-49. 